\title{
Effects of online marketing on Iranian ecotourism industry: Economic, sociological, and cultural aspects
}

\author{
Arash Riasi* and Shirin Pourmiri
}

University of Delaware, USA

\begin{tabular}{|c|c|}
\hline CHRON I C LE & A B S T R A C T \\
\hline $\begin{array}{l}\text { Article history: } \\
\text { Received March 25, } 2015 \\
\text { Received in revised format } \\
\text { August } 62015 \\
\text { Accepted August } 92015 \\
\text { Available online } \\
\text { August } 102015 \\
\text { Keywords: } \\
\text { Online marketing } \\
\text { Ecotourism } \\
\text { Tourism marketing } \\
\text { Tourism industry } \\
\text { Hospitality industry } \\
\text { Nature tourism } \\
\text { Travel agents }\end{array}$ & $\begin{array}{l}\text { This study intends to evaluate the impacts of implementing online marketing strategies on } \\
\text { Iranian ecotourism industry. The study had eight hypotheses which were designed based on } \\
\text { economic, sociological, and cultural aspects of Iranian ecotourism industry. The results } \\
\text { indicate that the expansion of online marketing increased the number of foreign tourists who } \\
\text { visited Iran's natural tourist attractions, while it had no significant impact on the number of } \\
\text { domestic tourists who visited these tourist attractions. The results also indicated that online } \\
\text { marketing did not increase the amount of investment in Iranian ecotourism industry. } \\
\text { Additionally, online ecotourism marketing did not have a significant influence on the total } \\
\text { number of travels to Iran's historical tourist attractions. Respondents believe implementing } \\
\text { online marketing strategies in Iranian ecotourism industry helps Iran expand its cultural } \\
\text { tourism in rural areas and it expands its hospitality industry; they also believe that online } \\
\text { marketing helps to create more jobs in Iranian ecotourism industry and to improve working } \\
\text { conditions in this industry. }\end{array}$ \\
\hline
\end{tabular}

\section{Introduction}

Ecotourism is usually defined as responsible travel to natural areas that conserves the environment and improves the well-being of local people (The International Ecotourism Society, 1990). Ecotourism has many benefits particularly for the economy of remote areas; ecotourism helps to support livelihood diversification in these areas, has very low market entry barriers, is labor intensive and can potentially grow fast even with unspecialized labor (Das \& Chatterjee, 2015; Holland et al., 2003). On the other hand, the promotion of local livelihoods by using ecotourism has been considered as a vital policy instrument for conserving biodiversity (Cattarinich, 2001; Das \& Chatterjee, 2015; Lai \& Nepal, 2006; Riasi, 2004; Scheyvens, 2007). The goal of ecotourism is to provide economic growth, social empowerment, conservation of natural resources and improving livelihood activities (Abbot et al., 2001; Das \& Chatterjee, 2015; Kiss, 2004; Salafsky \& Wollenberg, 2000; Shah, 2007). Even though

\footnotetext{
* Corresponding author. Tel: +1 (302)-898-6249

E-mail address: riasi@udel.edu (A. Riasi) 
ecotourism is considered as a source of income for many countries, some critics believe that it contributes to environmental destruction (Das \& Chatterjee, 2015). For this reason, many authors suggest that tourism industry has to grow sustainably and environmental issues should be taken into consideration very carefully (Balmford et al., 2002; Holden, 2003; Mihalic, 2000; Sharpley, 2000; Tepelus \& Cordobci, 2005). The main purpose of ecotourism is to provide financial benefits and empowerment for local residents (Mohamadi Kermani \& Hoseinian, 2001). In order to expand ecotourism industry and to convince potential tourists to choose ecotourism, it is important to use disparate marketing strategies. One of the best ways to attract more visitors to these tourist attractions is to use online marketing (Riasi, 2004). With the rapid evolution of information technology in today's world, tourism industry has entered an E-commerce age (Guo et al., 2014) and online marketing is one of the core contributors to this change. Tourists are becoming more and more dependent on online travel agencies (OTAs) for planning their trips (Guo et al., 2013), but online marketing is not limited to OTAs; providing online hotel reservation services, virtual tours, e-brochures and travel guides, and itinerary planning websites are other examples of online marketing in ecotourism industry.

Internet has helped ecotourism firms provide information about ecotourism destinations and facilitate travel arrangements (Dorsey et al., 2004). In recent years, Iranian ecotourism industry started to use online marketing strategies in order to attract more tourists from around the world. It is necessary to evaluate the effects of implementing these online marketing strategies on Iranian ecotourism industry to see whether these strategies helped this industry to become more profitable or not. Tourism can be considered as an alternative form of export because it helps to create new jobs, contributes to improving a country's balance of payments, and helps to generate tax revenues (Archer, 1995; Belisle \& Hoy, 1980; Davis et al., 1988; Durbarry, 2002; Khan et al., 1990; Pablo-Romero \& Molina, 2013; Riasi, 2004; Uysal \& Gitelson, 1994; West, 1993); therefore tourism industry and in particular ecotourism industry are considered as engines of economic growth for a country. There is some evidence that tourism fosters growth to a greater extent in low-income countries compared to high-income countries (Eugenio-Martín et al., 2004; Lee \& Chang, 2008; Seetanah, 2011). This study intends to evaluate the effects of online marketing on disparate aspects of this industry including economic, sociological, and cultural aspects.

\section{Ecotourism industry and online marketing}

Ecotourism industry can be defined in various ways, and for this reason many different terms are used to introduce this industry, including nature tourism, low-impact tourism, green tourism, bio-tourism, and ecologically responsible tourism (Tuohino \& Hynonen, 2001). Governments usually define ecotourism industry as a financial source for their countries while environmental organizations generally insist that ecotourism is nature-based, sustainably managed, conservation supporting, and environmentally educated (Buckley, 1994; Tuohino \& Hynonen, 2001). According to Hassan (2000) "It is critical for future destination development plans to be compatible with market needs and environment integrity for the industry to maintain its economic viability". One important issue in ecotourism industry is that the concept of ecotourism is not well understood in many countries. Ahmad (2014) in a study on Brunei Darussalam found that although many people acknowledge the importance and appropriateness of ecotourism, but they do not have sufficient knowledge about the concept of ecotourism. This is while the government of Brunei Darussalam supports the natural tourist attractions of the country and ecotourism has been identified as an appropriate type of tourism to be developed in this country (Ahmad 2014; Ahmad, 2011; GBD, 2007).

Iranian ecotourism industry is relatively new, and has a great potential for growth since there are many natural attractions in different regions of this country. Currently most of these tourist attractions are not listed as tourist destinations by travel agents and this is mainly due to the low amount of investments in this industry (Omrani, 2011). The main reason that investors are practically reluctant to invest in this industry is that there is not too much demand for visiting these natural tourist attractions. This is mainly because there is not enough advertisement on ecotourism (Asgharizade \& Mousavi, 2012). Internet 
provides a noble electronic commerce medium for ecotourism; it provides the primary mechanism for promoting ecotourism opportunities and for planning ecotourism experiences (Donohoe \& Needham, 2008). Although in online marketing the audience is more fragmented, but the companies have the possibility to combine various types of information in one intricate message (Gurau, 2008) and this makes online marketing more interesting for travel agencies. The advance of Internet technology has contributed to the online marketing of ecotourism destinations to a large extent (Lai \& Shafer, 2005). In recent years there have been new efforts to use online marketing to increase the profitability of Iranian ecotourism industry. There are now many websites which offer one-day tours to Iran's natural tourist attractions and many travel agents have worked with their international partners in order to attract foreign visitors (Mohamadi Kermani \& Hoseinian, 2001). Records show that the number of Iranian ecotourism marketing websites has been largely increased in recent years and it seems that this trend is likely to be continued, because the growing number of internet users in Iran will help these websites to attract more viewers each year (Fig. 1).

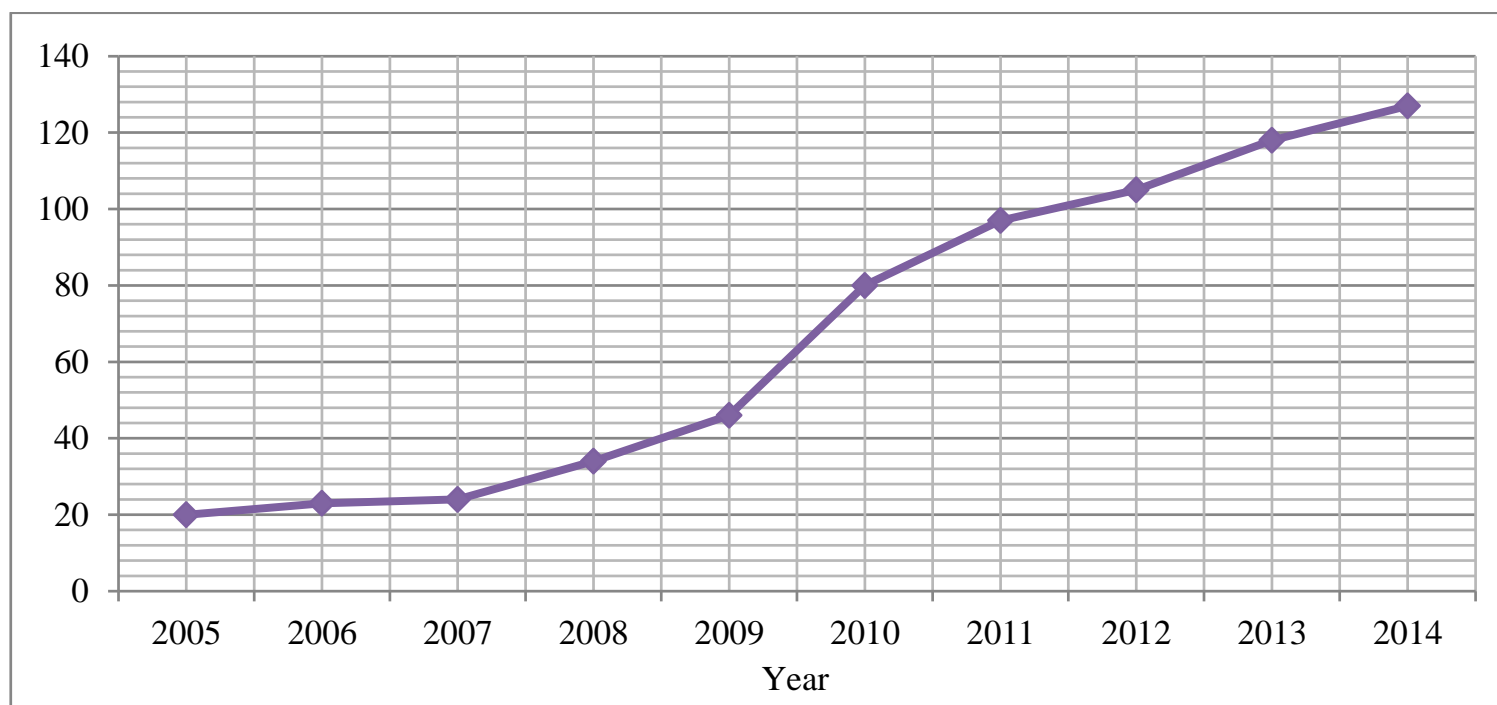

Fig. 1. Number of Iranian ecotourism marketing websites in the last 10 years

Iran has always been famous for its historical tourist attractions among foreign travelers but in recent years the implementation of online marketing strategies helped the country's ecotourism industry attract more foreign travelers and to increase its annual foreign exchange earnings (Rezaii et al., 2013; Riasi, 2004). In order to achieve competitive advantage over international rivals, Iranian industries should pay more attention to market demands (Amiri Aghdaie et al., 2012; Riasi, 2015a; Riasi, 2015b; Riasi \& Asadzadeh, 2015); this is particularly true for Iranian ecotourism industry since there is currently a large gap between tourists' demands and available facilities. Ecotourism can contribute to the economic growth of a region if it will be taken seriously. Mohammadi et al. (2012) performed a study on Seydan -a historical place in Southwest Iran- in order to find the effects of ecotourism on the economic development of this region; their results suggested that ecotourism significantly contributed to the economic growth of this region. According to Mobaraki et al. (2014) one of the best ways to develop ecotourism is to better identify disparate regions that have capacity for attracting tourists; they also suggest that creating infrastructures in these regions is an important issue. In another research, Firoozi et al. (2012) found a meaningful relationship between the absence of advertisement and ecotourism marketing and the number of tourists who visited Bavan Valley which is a famous ecotourism destination in Southern Iran. Qaemi (2012) in a study about ecotourism of Qeshm island an ecotourism destination in Persian Gulf- found a positive relationship between tourism destination brand awareness, brand equity, brand image, and brand loyalty. In another study, Azad et al. (2014) found that pricing strategy, tourism services and amenities, content of trip, marketing mix elements, and brand equity had a meaningful impact on gaining competitive advantage in tourism industry. Persuading foreign investors to invest in Iranian green industries will enable these industries to take 
advantage of new production technologies, supply chain management methods (Riasi, 2015a), and marketing strategies. Another important issue in online marketing is brand management. A large number of foreign tourists who visit Iran are backpackers. Backpackers are usually young tourists who participate in small and self-arranged travel groups (Hsu, 2014; Theuns, 1992). Online ecotourism marketing websites are a very good source of information for backpackers and in many cases these websites are the only available source of information for them during their trips. A major consideration for online ecotourism marketing websites is that they should provide special webpages for backpackers and they should have in mind that a lot of heterogeneity exists within specific backpacker segments (Ateljevic \& Doorne, 2005; Hecht \& Martin, 2006; Maoz, 2007; Riasi, 2004; Uriely et al., 2002).

\section{Methodology}

The main objective of this study was to evaluate the effects of online marketing on Iranian ecotourism industry. The size of the statistical society of this research was 865 which included travel agency managers and managers of ecotourism marketing websites. Because participants in a decision-making process tend to overstate their own influence (Atuahene-Gima \& Evangelista, 2000), the respondents chosen for this research were senior managers, to whom staff from different areas within a business unit report. In order to choose a sample of 50 managers, stratified random sampling was used. The reason to use stratified random sampling was that subpopulations within the overall population varied. The sample included 37 travel agency managers and 13 managers from ecotourism marketing websites. Travel agency managers who answered the questionnaires were from travel agencies located in Isfahan, Tehran, Mashhad, and Shiraz. Fig. 2 shows the personal characteristics of questionnaire respondents.

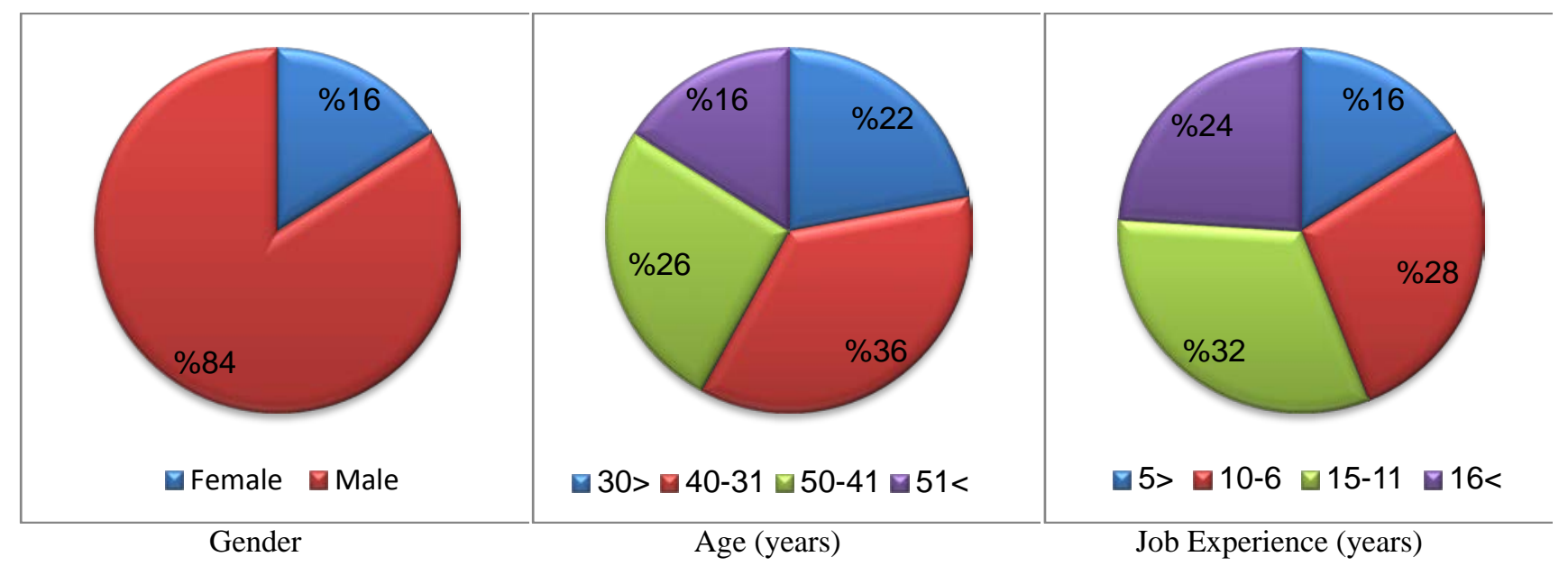

Fig. 2. Personal characteristics of the questionnaire respondents

(The figure shows the percentage of managers in each category)

In order to accept or reject the research's hypotheses, a questionnaire with 48 questions was created; each statement in the questionnaire was scored on a 7-point Likert scale ranging from 1 to 7 . The questions and hypotheses were designed based on economic, sociological, and cultural aspects of Iranian ecotourism industry. The study had eight hypotheses:

1) The total number of domestic tourists who visited Iran's natural tourist attractions increased as a result of implementing online marketing strategies in this industry.

2) The total number of foreign tourists who visited Iran's natural tourist attractions increased as a result of implementing online marketing strategies in this industry. 
3) Investment in Iranian ecotourism industry increased as a result of implementing online marketing strategies in this industry.

4) Travels to Iran's historical tourist attractions have been decreased as a result of implementing online marketing strategies in the country's ecotourism industry.

5) Implementing online marketing strategies in Iranian ecotourism industry, helps the country to expand its cultural tourism in rural areas.

6) Implementing online marketing strategies in Iranian ecotourism industry, helps the country to expand its hospitality industry.

7) Online marketing helps to create more job opportunities in Iranian ecotourism industry.

8) Implementing online marketing strategies in Iranian ecotourism industry, helps to improve working conditions in this industry.

To check the reliability of the research questionnaire, internal consistency and split-half methods were used. The Cronbach's alpha (Cronbach, 1951) was calculated with SPSS software. The questionnaire's Cronbach's alpha was 0.83, indicating suitable internal consistency and reliability. In the split-half analysis, results indicated that Cronbach's alpha was 0.85 for the first 24 questions of the questionnaire, and 0.81 for the latter 24 questions. Since the difference between the two amounts was not significant, the reliability of the questionnaire was accepted. In order to confirm the validity of the questionnaire, its content validity was examined. The content validity was unanimously accepted by a group of four experts including two faculty members and two professional travel agents.

In order to accept or reject the research's hypotheses, one-sample t-test was conducted with the use of SPSS software. One sample t-test assesses whether a sample value differs from the hypothesized value or not. In other words it measures whether the mean of a normally distributed population has a value specified in the null hypothesis. The one-sample t-test is used when we have a normal population or $n$ $>30$ while $\sigma$ is unknown. In testing the null hypothesis that the populations mean is equal to a specified value $\mu$, one uses the following formula:

$$
\mathrm{t}=\frac{\overline{\mathrm{x}}-\mu_{0}}{\mathrm{~s} / \sqrt{\mathrm{n}}}
$$

where $\bar{x}$ is the sample mean, $s$ is the sample standard deviation of the sample and $n$ is the sample size. The degrees of freedom used in this test was $n-1$. In Order to calculate the amount of the sample standard deviation (s), one uses the following formula:

$$
s=\sqrt{\frac{1}{N-1} \sum_{i=1}^{N}\left(x_{i}-\bar{x}\right)^{2}},
$$

where $N-1$ equals the number of degrees of freedom in the vector of residuals $\left(x_{1}-\bar{x}, \ldots, x_{n}-\bar{x}\right)$ (Azar \& Momeny, 2010). Once a t-value is determined, a p-value can be found using a table of values from Student's t-distribution. If the calculated p-value is below the statistical significance level (0.05), then the null hypothesis (H0) is rejected in favor of the alternative hypothesis (H1). In order to find the p-value we used right-tailed hypothesis testing.

Before performing the t-test, Kolmogorov-Smirnov test (KS test) was done in order to make sure that the data were normally distributed. For this test, the confidence level was set at 95 percent. According 
to KS test results the $\mathrm{P}$ for our data was equal to 0.54 . Since $\mathrm{P}=0.54$ is higher than 0.05 , the null hypothesis was accepted and it was concluded that our data followed a normal distribution with mean $=0.2841$ and standard deviation $=1.098$.

\section{Results}

\subsection{First Hypothesis}

H0: The total number of domestic tourists who visited Iran's natural tourist attractions did not increase as a result of implementing online marketing strategies in this industry.

H1: The total number of domestic tourists who visited Iran's natural tourist attractions increased as a result of implementing online marketing strategies in this industry.

Because the p-value of 0.073 is more than 0.05 , hypothesis $\mathrm{H} 0$ is accepted and hypothesis $\mathrm{H} 1$ is rejected at the $95 \%$ confidence level (Table 1).

\section{Table 1}

First hypothesis at 95\% confidence level

\begin{tabular}{cccc}
\hline t-value & p-value & DF & Statistical Significance Level \\
\hline 1.475 & 0.073 & 49 & 0.05 \\
\hline
\end{tabular}

\subsection{Second Hypothesis}

H0: The total number of foreign tourists who visited Iran's natural tourist attractions did not increase as a result of implementing online marketing strategies in this industry.

H1: The total number of foreign tourists who visited Iran's natural tourist attractions increased as a result of implementing online marketing strategies in this industry.

Because the p-value of 0.013 is less than 0.05 , hypothesis $\mathrm{H} 0$ is rejected and hypothesis $\mathrm{H} 1$ is accepted at the $95 \%$ confidence level (Table 2 ).

\section{Table 2}

Second hypothesis at 95\% confidence level

\begin{tabular}{cccc}
\hline t-value & p-value & DF & Statistical Significance Level \\
\hline 2.312 & 0.013 & 49 & 0.05 \\
\hline
\end{tabular}

\subsection{Third Hypothesis}

H0: Investment in Iranian ecotourism industry did not increase as a result of implementing online marketing strategies in this industry.

H1: Investment in Iranian ecotourism industry increased as a result of implementing online marketing strategies in this industry.

Because the p-value of 0.114 is more than 0.05 , hypothesis $\mathrm{H} 0$ is accepted and hypothesis $\mathrm{H} 1$ is rejected at the $95 \%$ confidence level (Table 3).

\section{Table 3}

Third hypothesis at 95\% confidence level

\begin{tabular}{cccc}
\hline $\mathrm{t}$-value & $\mathrm{p}$-value & $\mathrm{DF}$ & Statistical Significance Level \\
\hline 1.223 & 0.114 & 49 & 0.05 \\
\hline
\end{tabular}




\subsection{Fourth Hypothesis}

H0: Travels to Iran's historical tourist attractions have not been decreased as a result of implementing online marketing strategies in the country's ecotourism industry.

H1: Travels to Iran's historical tourist attractions have been decreased as a result of implementing online marketing strategies in the country's ecotourism industry.

Because the p-value of 0.194 is more than 0.05, hypothesis $\mathrm{H} 0$ is accepted and hypothesis $\mathrm{H} 1$ is rejected at the $95 \%$ confidence level (Table 4).

\section{Table 4}

Fourth hypothesis at 95\% confidence level

\begin{tabular}{cccc}
\hline t-value & p-value & DF & Statistical Significance Level \\
\hline 0.872 & 0.194 & 49 & 0.05 \\
\hline
\end{tabular}

\subsection{Fifth Hypothesis}

H0: Implementing online marketing strategies in Iranian ecotourism industry, does not help the country to expand its cultural tourism in rural areas.

H1: Implementing online marketing strategies in Iranian ecotourism industry, helps the country to expand its cultural tourism in rural areas.

Because the p-value of 0.006 is less than 0.05 , hypothesis $\mathrm{H} 0$ is rejected and hypothesis $\mathrm{H} 1$ is accepted at the $95 \%$ confidence level (Table 5).

\section{Table 5}

Fifth hypothesis at 95\% confidence level

\begin{tabular}{cccc}
\hline t-value & p-value & DF & Statistical Significance Level \\
\hline 2.641 & 0.006 & 49 & 0.05 \\
\hline
\end{tabular}

\subsection{Sixth Hypothesis}

H0: Implementing online marketing strategies in Iranian ecotourism industry, does not help the country to expand its hospitality industry.

H1: Implementing online marketing strategies in Iranian ecotourism industry, helps the country to expand its hospitality industry.

Because the p-value of 0.043 is less than 0.05 , hypothesis $\mathrm{H} 0$ is rejected and hypothesis $\mathrm{H} 1$ is accepted at the $95 \%$ confidence level (Table 6).

Table 6

Sixth hypothesis at 95\% confidence level

\begin{tabular}{cccc}
\hline t-value & p-value & DF & Statistical Significance Level \\
\hline 1.751 & 0.043 & 49 & 0.05 \\
\hline
\end{tabular}

\subsection{Seventh Hypothesis}

H0: Online marketing does not help to create more job opportunities in Iranian ecotourism industry.

H1: Online marketing helps to create more job opportunities in Iranian ecotourism industry.

Because the p-value of 0.032 is less than 0.05 , hypothesis $\mathrm{H} 0$ is rejected and hypothesis $\mathrm{H} 1$ is accepted at the $95 \%$ confidence level (Table 7 ). 
Table 7

Seventh hypothesis at 95\% confidence level

\begin{tabular}{cccc}
\hline t-value & p-value & DF & Statistical Significance Level \\
\hline 1.902 & 0.032 & 49 & 0.05 \\
\hline
\end{tabular}

\subsection{Eighth Hypothesis}

H0: Implementing online marketing strategies in Iranian ecotourism industry, does not help to improve working conditions in this industry

H1: Implementing online marketing strategies in Iranian ecotourism industry, helps to improve working conditions in this industry

Because the p-value of 0.025 is less than 0.05 , hypothesis $\mathrm{H} 0$ is rejected and hypothesis $\mathrm{H} 1$ is accepted at the $95 \%$ confidence level (Table 8).

Table 8

Eighth hypothesis at 95\% confidence level

\begin{tabular}{cccc}
\hline t-value & p-value & DF & Statistical Significance Level \\
\hline 2.012 & 0.025 & 49 & 0.05 \\
\hline
\end{tabular}

\section{Discussion}

The results indicated a great increase in the number of foreign tourists who visited Iran's natural tourist attractions after the implementation of online marketing strategies in this industry. This indicates that online marketing helped Iranian ecotourism industry to penetrate international markets. In contrast, the results indicated that the number of domestic tourists who visited Iran's natural tourist attractions did not significantly increase after the implementation of online marketing strategies in this industry. A possible explanation of this is that since many Iranian households do not have access to the internet, their exposure to online ecotourism advertisements was not significant enough to increase the total number of Iranians who visited natural tourist attractions of their country. Another explanation is that since Iranian people do not rely on online advertisements (Farhadian \& Mehrdoust, 2012), they did not react positively to online marketing strategies which were used by travel agents.

Although the results indicated that the number of foreign tourists who visited Iran's natural tourist attractions increased after implementation of online marketing strategies in Iranian ecotourism industry, but Investment in Iranian ecotourism industry did not increase. A possible explanation for this is that unstable economic conditions in Iran is discouraging for foreign investors; this is while low-priced labor in Iran can be encouraging for international investors (Riasi \& Amiri Aghdaie, 2013).

The results also indicated that travels to Iran's historical tourist attractions did not decrease after implementing online marketing strategies in the country's ecotourism industry. One explanation for this is that since the number of domestic tourists who visited natural tourist attractions did not significantly increase, there was no decline in the number of tourists who visited Iran's historical tourist attractions.

The results showed that implementing online marketing strategies in Iranian ecotourism industry helps the country to expand its cultural tourism in rural areas. According to Stebbins (1996) "Cultural tourism is a genre of special interest tourism based on the search for and participation in new and deep cultural experiences, whether aesthetic, intellectual, emotional, or psychological". Since most of Iran's natural tourist attractions are located near rural areas, ecotourism and cultural tourism in these areas have strong connections. Cultural attractions in rural areas of Iran include listening to traditional music, eating traditional foods and drinks, watching traditional ceremonies, and buying handcrafts from local people. In recent years, many ecotourism marketing websites have started to introduce these cultural attractions 
to their customers in order to make their ecotourism tours more appealing. As a result of this, the respondents to this research's questionnaires believed that online marketing in ecotourism industry positively affects cultural tourism in Iran.

The respondents believed that implementing online marketing strategies in Iranian ecotourism industry helps the country to expand its hospitality industry. Ecotourism marketing websites work with hotels, car rental companies, restaurants and other components of hospitality industry; the respondents believed that ecotourism marketing websites frequently force these components of hospitality industry to improve the quality of their services and to offer more online services.

Based on the responses to the questionnaires, online marketing helps to create more job opportunities in Iranian ecotourism industry and also helps to improve working conditions in this industry. The growing number of ecotourism marketing websites helps to create more job positions in ecotourism industry. Each new ecotourism marketing website recruits around 10 employees and all of these job positions have relatively high-quality working conditions. Respondents believed that the expansion of online marketing in ecotourism industry also helps to remove unnecessary jobs and at the same time helps to create jobs with more suitable working environment. One reason for the high-quality working conditions at ecotourism marketing websites is that the employees at these companies have a very safe working environment. Another reason for this is that, because of the nature of online marketing, employees can have flexible working hours. Additionally, Iranian ecotourism marketing websites usually pay high salaries to their employees. As a result of this, there is a great demand for working at an ecotourism marketing website. Iranian ecotourism marketing websites are good examples of learning organizations, because they facilitate the learning process for their employees, adapt themselves with new technologies, and choose new methods for penetrating new markets. Working at a learning organization is equal to working under high-quality working conditions, and this is another point which makes a career at an ecotourism marketing website more enjoyable for its employees.

\section{Research Limitations}

Since the data were collected through a questionnaire, the results of this study are evaluations based on the current conditions in Iranian ecotourism industry rather than hard observational data. Moreover, since the implementation of online marketing strategies in Iranian ecotourism industry is a moderately new issue, it was not possible to evaluate its long term effects on this industry.

\section{Conclusion}

The results suggest that online marketing positively affected some aspects of Iranian ecotourism industry but it was not successful in attracting more domestic tourists to the country's natural tourist attractions and it did not help to increase the amount of investment in this industry. While online marketing was not prosperous in attracting domestic tourists, it helped Iranian ecotourism industry to attract more foreign visitors and as a result of this the industry was supplied with more foreign exchange earnings. Implementing online marketing strategies also had positive effects on cultural tourism, hospitality industry, working conditions, and the job market.

\section{References}

Abbot, J.I.O., Thomas, D.H.L., Gardner, A.A., Neba, S.E., \& Khen, M.W. (2001). Understanding the links between conservation and development in the Bamenda Highland, Cameroon. World Development, 29(7), 1115-1136.

Ahmad, A. (2011). Ecotourism in Brunei Darussalam: An analysis of the impacts on indigenous communities. Germany: LAP Lambert Academic Publishing. 
Ahmad, A. (2014). The disengagement of the tourism businesses in ecotourism and environmental practices in Brunei Darussalam. Tourism Management Perspectives, 10, 1-6. DOI:10.1016/j.tmp.2013.12.002

Amiri Aghdaie, S. F., Seidi, M., \& Riasi, A. (2012). Identifying the Barriers to Iran's Saffron Export by Using Porter's Diamond Model. International Journal of Marketing Studies, 4(5), 129-138. DOI:10.5539/ijms.v4n5p129

Archer, B. (1995). Importance of tourism for the economy of Bermuda. Annals of Tourism Research, 22(4), 918-930.

Asgharizade, A., \& Mousavi M. H. (2012). Social and financial barriers against ecotourism expansion in Iran. Iranian journal of research in nature tourism management, 4(2), 48-59.

Ateljevic, I., \& Doorne, S. (2005). Dialectics of authentication: Performing 'exotic otherness' in a backpacker enclave of Dali, China. Journal of Tourism and Cultural Change, 3(1), 1-17.

Atuahene-Gima, K., \& Evangelista, F. (2000). Cross-functional influence in new product development: An exploratory study of marketing and R\&D perspectives. Management Science, 46(10), 12691284.

Azad, N., Safaei, M., \& Farahani, M. (2014). A study on the effects of different factors influencing on customer loyalty, profitability and word of mouth advertisement for gaining competitive advantage in tourism industry. Management Science Letters, 4(6), 1099-1102. DOI:10.5267/j.msl.2014.5.023

Azar, A., \& Momeny, M. (2010). Statistics and Its Application in Management: (Vol 2): Statistical Analysis (Third edition). Tehran: The Organization for Researching and Composing University Textbooks in the Humanities.

Balmford, A., Bruner, A., Cooper, P., Costanza, R., Farber, S., Green, R.E., et al. (2002). Economic reasons for conserving wild nature. Science, 297(5583), 950-953.

Belisle, F., \& Hoy, D. (1980). The perceived impact of tourism by residents. Annals of Tourism Research, 8, 83-97.

Buckley, R. (1994). Research Note, a framework for ecotourism. Annals of Tourism Research, 21(3), 661-669.

Cattarinich, X. (2001). Pro-poor tourism initiatives in developing countries: Analysis of secondary case studies. PPT working paper no. 8 (Retrieved on 22nd August, 2013 from http://195.130.87.21:8080/dspace/bitstream/123456789/449/1/Propoor\%20tourism\%20initiatives \%20in\%20developing\%20countries\%20analysis\%20of\%20secondary\%20case\%20studies.pdf).

Cronbach, L. J. (1951). Coefficient alpha and the internal structure of tests. psychometrika, 16(3), 297334.

Das, M., \& Chatterjee, B. (2015). Ecotourism: A panacea or a predicament?.Tourism Management Perspectives, 14, 3-16. DOI:10.1016/j.tmp.2015.01.002

Davis, D., Allen, J., \& Consenza, R. M. (1988). Segmenting local residents by their attitudes, interests, and opinions toward tourism. Journal of Travel Research, 27(2), 2-8.

Donohoe, H. M., \& Needham, R. D. (2008). Internet-based ecotourism marketing: Evaluating Canadian sensitivity to ecotourism tenets. Journal of Ecotourism, 7(1), 15-43.

Dorsey, E. R., Steeves, H. L., \& Porras, L. E. (2004). Advertising ecotourism on the internet: commodifying environment and culture. New Media \& Society, 6(6), 753-779.

Durbarry, R. (2002). The economic contribution of tourism in Mauritius. Annals of Tourism Research, 29(3), 862-865

Eugenio-Martín, J. L., Morales, N. M., \& Scarpa, R. (2004). Tourism and economic growth in Latin American countries: A panel data approach. Fondazione Eni Enrico Mattei Working Paper Series, Nota di Lavoro, 26.

Farhadian, S. A., \& Mehrdoust, F. (2012). Do young Iranian people trust online shopping stores and online advertisements? West Asian journal of electronic trading, 1(3), 76-84.

Firoozi, M., Goodarzi, M., \& Akbari, A. (2012). Analyzing the role of Bavan Valley in Mamasani as tourists attraction. Management Science Letters, 2(7), 2449-2456. DOI:10.5267/j.msl.2012.07.022

GBD (Government of Brunei Darussalam) (2007). Brunei Darussalam long-term development plan. Bandar Seri Begawan: Prime Minister's Office. 
Guo, X., Ling, L., Dong, Y., \& Liang, L. (2013). Cooperation contract in tourism supply chains: The optimal pricing strategy of hotels for cooperative third party strategic websites. Annals of Tourism Research, 41, 20-41.

Guo, X., Zheng, X., Ling, L., \& Yang, C. (2014). Online coopetition between hotels and online travel agencies: From the perspective of cash back after stay. Tourism Management Perspectives, 12, 104112.

Gurau, C. (2008). Integrated online marketing communication: implementation and management. Journal of communication management, 12(2), 169-184.

Hassan, S. S. (2000). Determinants of market competitiveness in an environmentally sustainable tourism industry. Journal of travel research, 38(3), 239-245.

Hecht, J. -A., \& Martin, D. (2006). Backpacking and hostel-picking: An analysis from Canada. International Journal of Contemporary Hospitality Management, 18(1), 69-77.

Holden, A. (2003). In need of new environmental ethics for tourism. Annals of Tourism Research, 30(1), 94-108

Holland, J., Burian, M., \& Dixey, L. (2003). Tourism in poor rural areas. PPT working paper no. 12. ODI, IIED, ICRT (Retrieved on 25th August, 2013 from http://www.odi.org.uk/RPEG/PPT/WP12).

Hsu, J. L., Wang, T. C. T., \& Huang, P. Y. H. (2014). Motivations for first-time and repeat backpackers in Shanghai. Tourism Management Perspectives, 12, 57-61. DOI: 10.1016/j.tmp.2014.08.001

Khan, H., Seng, C., \& Cheong, W. (1990). Tourism multipliers effects on Singapore. Annals of Tourism Research, 17, 408-418.

Kiss, A. (2004). Is community-based ecotourism (CBET) a good use of biodiversity conservation? Trends in Ecology \& Evolution, 19(5), 232-237.

Lai, P.H., \& Nepal, S.K. (2006). Local perspectives of ecotourism development in Tawushan Nature Reserve, Taiwan. Tourism Management, 27(6), 1117-1129.

Lai, P. H., \& Shafer, S. (2005). Marketing ecotourism through the Internet: An evaluation of selected ecolodges in Latin America and the Caribbean. Journal of Ecotourism, 4(3), 143-160.

Lee, C. -C., \& Chang, C. -P. (2008). Tourism development and economic growth: A closer look to panels. Tourism Management, 29, 80-192.

Maoz, D. (2007). Backpackers' motivations: The role of culture and nationality. Annals of Tourism Research, 34(1), 122-140.

Mihalic, T. (2000). Environmental management of a tourist destination: A factor of tourism competitiveness. Tourism Management, 21(1), 65-75.

Mobaraki, O., Abdollahzadeh, M., \& Kamelifar, Z. (2014). Site suitability evaluation for ecotourism using GIS and AHP: A case study of Isfahan Townships, Iran. Management Science Letters, 4(8), 1893-1898. DOI: 10.5267/j.msl.2014.6.038

Mohammadi, J., Ahmadi, D., \& Godarzi, M. (2012). An analysis Seydan ecotourism with emphasis on sustainable development. Management Science Letters, 2(6), 2019-2024. DOI:10.5267/j.msl.2012.06.019

Mohamadi Kermani, A. S., \& Hoseinian, M. (2001). Why Iranian ecotourism industry growth is important? Iranian Journal of Innovations in Marketing Management, 1(3), 66-73.

Omrani, S. E. (2011). The need for the expansion of Iran's hotel business in ecotourism: A case study of Hormozgan province. Iranian journal of research in nature tourism management, 3(1), 65-72.

Pablo-Romero, M. D. P., \& Molina, J. A. (2013). Tourism and economic growth: A review of empirical literature. Tourism Management Perspectives, 8, 28-41.

Qaemi, V. (2012). An empirical survey on perceived value from tourism destination based on brand equity model: A case study of Qeshm Island. Management Science Letters, 2(7), 2347-2354. DOI: 10.5267/j.msl.2012.08.008

Rezaii, M., Rahmani H., \& Dehkourdi, M. J. (2013). Tourism business in Iran: an overview of recent economical trends with focus on international trade. Iranian Academy of Executive Studies Journal, 4(1), 59-70.

Riasi, A. (2004). Introducing some of the most famous tourist attractions of Iran and the world, Mashhad: Sokhan Gostar Publication. DOI: 10.13140/RG.2.1.1101.8088 
Riasi, A. (2015a). Barriers to international supply chain management in Iranian flower industry. Management Science Letters, 5(4), 363-368. DOI: 10.5267/j.msl.2015.2.005

Riasi, A. (2015b). Competitive Advantages of Shadow Banking Industry: An Analysis Using Porter Diamond Model. Working Paper

Riasi, A., \& Amiri Aghdaie, S. F. (2013). Effects of a Hypothetical Iranian Accession to the World Trade Organization on Iran's Flower Industry. Consilience: The Journal of Sustainable Development, 10(1), 99-110.

Riasi, A., \& Asadzadeh, N. (2015). The relationship between principals' reward power and their conflict management styles based on Thomas-Kilmann conflict mode instrument. Management Science Letters, 5(6), 611-618. DOI: 10.5267/j.msl.2015.4.004

Salafsky, N., \& Wollenberg, E. (2000). Linking livelihoods and conservation: A conceptual framework and scale for assessing the integration of human needs and biodiversity. World Development, 28(8), $1421-1438$

Scheyvens, R. (2007). Exploring the tourism-poverty nexus. In C.M. Hall (Ed.), Pro-poortourism: Who benefits? Perspectives on tourism and poverty reduction (pp. 121-144). Clevedon, England: Channel View.

Seetanah, B. (2011). Assessing the dynamic economic impact of tourism for island economies. Annals of Tourism Research, 38(1), 291-308.

Shah, A. (2007, Jul. 14-20). Management of protected areas: Exploring an alternative in Gir. EPW, 42 (No. 27/28).

Sharpley, R. (2000). Tourism and sustainable development. Exploring the theoretical divide. Journal of Sustainable Tourism, 8(1), 1-19.

Stebbins, R. A. (1996). Cultural Tourism as Serious Leisure. Annals of Tourism Research. 23(4), 948950.

Tepelus, C.M., \& Cordobci, R.C. (2005). Recognition schemes in tourism— Fromeco to sustainability? Journal of Cleaner Production, 13(2), 135-140.

The International Ecotourism Society (TIES) (1990). What is Ecotourism? (Retrieved on 2nd September, 2013 from http://www.ecotourism.org/what-is-ecotourism).

Theuns, L. (1992). The significance of youth tourism: Economic dimensions. Acta Turistica, 4(2), 165-187.

Tuohino, A., \& Hynonen, A. (2001). Ecotourism - imagery and reality. Reflections on concepts and practices in Finnish rural tourism. Nordia Geographical Publications.

Uriely, N., Yonay, Y., \& Simchai, D. (2002). Backpacking experiences: A type and form analysis. Annals of Tourism Research, 29(2), 520-538.

Uysal, M., \& Gitelson, R. (1994). Assessment of economic impacts: Festivals and special events. Festival Management and Event Tourism, 2(1), 3-10.

West, G. R. (1993). Economic significance of tourism in Queensland. Annals of Tourism Research, 20(3), 490-504. 